\title{
Revisiting the concept of inculturation in a modern Africa: A reflection on salient issues
}

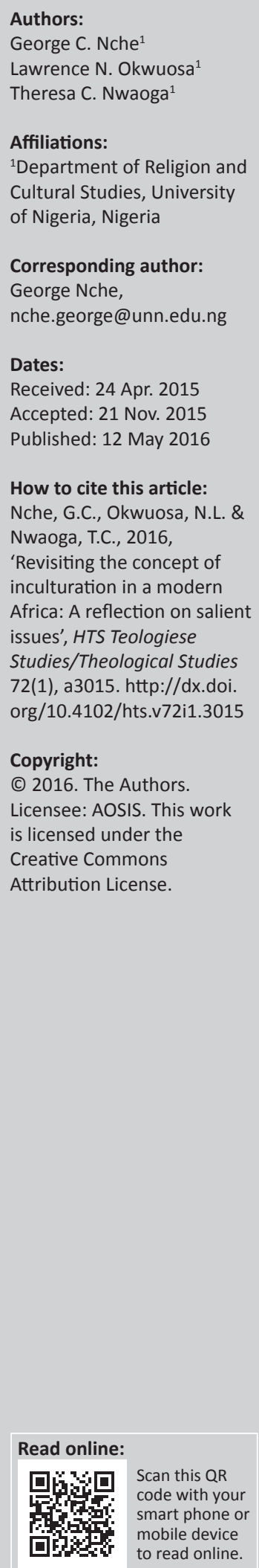

This article revisited the concept of 'Inculturation' in modern Africa. Through the use of a historical phenomenological method, the article averred that Inculturation of Christianity in modern Africa is a herculean task that demands absolute caution. Hence, the article discussed some salient issues such as the evolutionary nature of African culture; the unity of the Christendom; and the Christian ecological concern, which should be put into serious consideration in the entire process of inculturation in Africa to safeguard the essence of the gospel of Christ and to meet contemporary challenges.

\section{Introduction}

Over decades, the concept of inculturation has been on the front burner of theological discourse in the African continent and beyond. This was largely triggered by the Second Vatican Council held on 11 October 1962 at St. Peters Basilica in the Vatican in which a strong case was made for the cultural adaptation of Christianity in Africa. This idea has spawned into several concepts such as 'Acculturation', 'Enculturation', 'Interculturation', 'Incarnation', 'Africanisation', 'Adaptation', and 'Indigenisation' of Christianity in Africa. These concepts revolve around the idea of making the Christian faith culturally permissible and acceptable in Africa. According to John Paul II, 'A faith which does not become culture is a faith which has not been fully received, not thoroughly thought through, not fully lived out' (Ezechi 2011:221). Mbiti (1969) insightfully argued that because traditional religions occupy the whole person and the whole of his life, conversion to a new religion like Christianity must embrace language, thought patterns, fears, social relationships, attitudes, and philosophical disposition if that conversion is to make a lasting impact upon the individual and community. Hence, efforts over the years have been channelled towards a successful inculturation of Christianity which aims at making the church more at home in Africa, and Africans more at home in the church. This, of course, is in line with the declaration of the Second Vatican Council, which says that, the church 'is not tied exclusively or indissolubly to any race or nation, to any one particular way of life, or to any customary practices, ancient or modern' (Mbefo 1981:1).

But before these declarations of the Second Vatican Council, the need for a 'homemade' Christianity or African Christianity was conspicuously observed in the lives of African Christians. Indeed, 'so soon after the implanting of Christianity in Africa, and just as the foreign missionaries are arriving home...the love of many \{became\} cold' (Husani n.d.). Many African Christians became guilty of double standards as they could not disconnect completely from the primal or pristine religion of their fore-bearers and the values it offered. Hence, they paid double allegiance, as they became good Christians, when the going was smooth, but when it got tough, they resorted to their traditional religion. This is because Christianity as thought by the European missionaries gave rise to pertinent questions. Some of these questions which bother the typical African and for instance, an average Igbo man of Eastern Nigeria, include:

Does being a Christian mean that I cannot take the Ozo title? That I cannot bury my dead in the traditional way? Why should I change my name that arose out of my matrix and which has meaning and relevance in that matrix for a foreign name which people find difficult to pronounce; foreign names which are truly foreign? What does a celibate priesthood tell a polygamous culture? Why does the liturgy of the church bypass the liturgy of traditional religions that have always mediated transcendence to our people? (Mbefo 1989:4)

And more importantly, what happens to our ancestors who lived, loved, and died but are, in the words of Birago Diop, 'never gone'? These questions indeed hinge on the core cultural values of Africans expressed in symbols that appeal to their world of realities and experience. However, the European missionaries could not read meanings into all these things that interest the African man. Consequently, 'this, among other things, has resulted in the tragedy of establishing, since the missionary expansion of the nineteenth century only a very superficial type of Christianity on African soil' (Mbiti 1969:15). And according to Mbefo (1989:28) 'with the experienced massive 
defections from the church, one is disposed to affirm that Christianity as rendered by the Europeans has been found wanting'. Hence, the concept of inculturation formed one of the major themes at the Second Vatican Council on 11 October 1962, and the subsequent Synod of Bishops for Africa which took place in May, 1994.

The whole idea has been to make Christianity respond adequately to the facts and specifics of other world cultures, including African culture. To this effect, many theories on how to achieve a successful inculturation of Christianity into other cultures have been advanced. Although this is not a place to discuss these theories, it is pertinent to note that the process of inculturation is gradually in progress in Africa; and the methods are impressively eclectic.

However, there are some salient issues which should be put into serious consideration, while this inculturation process continues on the continent. The critical discussion of these salient issues is the main thrust of this article. It should also be noted that although the article addresses inculturation of Christianity as it concerns the entire African continent, many references shall be made to or drawn from the Roman Catholic tradition as the Catholics seem to be the first to engage with what is now known as inculturation.

\section{The concept of inculturation in Africa}

The basic notion of inculturation is the expression of the dynamic relation between the Christian gospel and world cultures for the consolidation of the faith (Ezechi 2011). It is a process or attempt to find or root Christianity in different cultures of the world. It is also a process whereby cultural values can be transformed through their exposure to the Christian message and the insertion of Christianity into indigenous cultures (Duncan 2014). Specifically, it refers to a movement for the Africanisation or indigenisation of Christianity in Africa. This became necessary, following the failure of the European missionaries to 'root the gospel message solidly unto the African word of meaning, realitystructure, survival thrust or the African conceptual framework' (Husani n.d.) - a failure, which resulted in a seemingly alienation and estrangement of the Christianity on African soil. This failure also made it difficult for Africans to 'separate the gem of Christianity from the chaffs or accidents of it' (Madu 2004:59). Buttressing this fact, Wambutda (1978) observed that the Christianity as imported from Europe and America contains strange and sometimes disgusting features of alienation with which Africans are most uncomfortable. Perhaps this prompted Pope Paul VI in 1975, to ask thus:

Does the church in Africa retain a certain Christian religious form that was brought in from outside and which makes her, as it were, a stranger or pilgrim among her people? Should new and more suitable means be sought in theology and in pastoral practice? (Mbefo 1989:9)

Christian faith should be made real in an African situation. Ezechi (2011:236) has observed that 'the Christian faith is one, but the manner of expression varies from time to time, from place to place'. Hence, inculturation is the contextualisation of the Christian faith. It responds to the immediate existential realities in a cultural milieu. This process, however, according to Yung (2014) can only be undertaken where there is already comprehension of the local culture as it relates to world views, ways of thinking, group solidarity, understanding of history, and of modernity and its impact.

According to the document titled 'The Roman Liturgy and Inculturation: Fourth Instruction for the Right Application of the Conciliar Constitution on the Liturgy', the process of inculturation in Africa was viewed from the perspective of 'Adaptation' in which Christianity adapts to African cultural facts. However, Shorter (1973) has argued that 'Adaptation' is a misnomer because it suggests that Christianity somehow adapts itself. In fact, because it is not in itself a culture, Christianity cannot adapt itself without betraying itself. He, instead, sees inculturation from the perspective of 'incarnation'.

This is in tandem with the position of the Synod of Bishops for Africa, which was held on 06 May 1994, with the theme 'The Church in Africa and Her Evangelising Mission, Towards the Third Millennium - You shall be my Witnesses'. The African Bishops established that the inculturation process can successfully be achieved in Africa if it is applied from the point of view of incarnation. Christianity, just like in the doctrine of Jesus' incarnation, should be incarnated, and wear the form of African culture in order to achieve the ultimate meaning in Africa. In the understanding of 'inculturation' as 'incarnation', Shorter (1973) wrote thus:

What really happens is that Christianity in one cultural dress encounters a non-Christian culture, and then tries to incarnate itself in the new culture. In doing this, it challenges and transforms the culture. Two processes are involved: the 'undressing' of Christianity from the foreign culture and the dressing of Christianity in the indigenous culture simultaneously - because you cannot have a culturally naked Christianity. (p. 69)

To Shorter, this is the best form of inculturation as against the preconciliar mission theological view of 'Adaptational Inculturation'. Buttressing this point, Ezechi (2011) observed that, the concept of incarnation with regards to inculturation recognises the position of the church as one that enters into a people's field of experience - their cultural milieu. It lives in that culture and speaks its language with a view to revalidating it from within. It is only when this is achieved in Africa that Christianity and the church can feel at home in Africa, and Africans at home in the church. Hence, in line with the position of the 1994 Synod of African Bishops, the Nigerian Bishops at a Workshop held in Enugu in January 1995, drew out a Plan of Action for Inculturation of Christianity in Nigeria in which they stated that:

- The spirit of inculturation must henceforth permeate the entire curriculum of studies in seminaries and theological institutes in the country. It is not enough to teach Inculturation as a course, or organise short seminars on Inculturation. The same spirit of inculturation must permeate our homilies, retreat talks, and seminars. 
- Beyond the mere translation of texts and the adaptation of symbols and artefacts, our Theological Institutes should take up the challenge of studying more deeply the African traditions, cultures, and religions, towards the eventual inculturation of Catholic Fundamental Theology, Liturgy, Spirituality, Canon Law, Ecclesiology, and Homiletics.

- Astanding Committee of the Catholic Bishops' Conference of Nigeria $(\mathrm{CBCN})$ on inculturation already exists. The various provinces, dioceses, parishes, and stations should have such committees on Inculturation, involving both the clergy and the laity.

- The Bishops' Conference should allow a period of experimentation on inculturation, encourage initiatives in inculturation, and possibly select particular parishes in each diocese for the purpose of inculturation.

- A new approach should be adopted towards African Traditional Religion; more effort should be made towards Christianising African values that will enrich Christianity, such as found in initiation rites, marriage ceremonies, title taking, etc.

- In Nigeria, inculturation should be promoted along the lines of language and cultural groups, rather than through the existing dioceses and provinces (Husani n.d.).

Furthermore, the core cultural areas that would be practically considered in the inculturation process in Nigeria, as identified by the $\mathrm{CBCN}$ include:

- Naming ceremony vis-a-vis sacrament of baptism and initiation rites.

- Inculturation of marriage.

- Prayers/Blessings to be composed for childless couples, different classes of sick people, etc.

- Rites for title taking and chieftaincy.

- Blessing for land and the beginning of the planting season, harvest time, and new yam festival.

- Composition of liturgical hymns in the vernacular.

- Study of witchcraft and African Traditional Religion.

- Writing of new textbooks relevant to African philosophy or world view for our Seminaries and religious houses (Husani n.d.).

These and more, go to show how seriously the task of inculturation is being taken in Nigeria, and Africa as a whole.

\section{Justifications for inculturation in Africa}

A critical study of the historic experience of Africans during the European missionary and colonial era as well as the literature on inculturation by authors of African extraction show some uniformity in the line of thought with respect to the major reasons for inculturation of Christianity in the continent. Some of these reasons have been identified as justifications for inculturation in Africa. They include the following:

\section{Christianity: A foreign religion}

Christianity as was rendered by the first European missionaries is a foreign religion, encoded in foreign culture. Okere (1974) has argued that it is perfectly natural that the Christianity preached to us was a heavily Europeanised one'. It was not tied to the culture of Africans, like the indigenous religion of their fore-bearers. It was not rooted in the valuable cultural values and norms of which Africans are known for. Indeed, this is a failure on the part of these missionaries. These missionaries introduced the Christian faith without taking 'African social facts and institutions into account' (Shorter 1973:157). They could not understand or find meaning in African cultural values expressed in their religious activities.

They rejected hitherto everything African, categorised them as barbaric and completely unholy for the Christian God. This rendered Africans as epitome of barbarism, morons, and primitive among other binary oppositions (Viriri \& Mungwim 2010). African names were substituted for English ones; and:

the age-grade system, the initiation rites that incorporate a person into society, the rites that celebrate the onset of pregnancy, birth, marriage, death and funeral ceremonies, harvest celebrations and other traditional feasts and festivals were often circumvented. (Husani n.d.)

These missionaries 'suppressed and supplanted the existing traditional religion and customs and replaced them with the imported religion of Christianity' (Onyeidu 2004:35). Indeed, it is to this extent that Africans see Christianity as a foreign religion.

On the contrary, however, attempts have been made to disprove this notion or belief that Christianity is a foreign religion. According to Mbefo (1989) the argument to debunk the notion exploits the concept of Katholikos (a Greek word meaning 'universal') to prove that Christianity is a universal religion. Accordingly, Onaiyekan (1980) argued that Christianity is really no-man's religion, but every man's religion. This makes the adequate inculturation of the Christian faith into world cultures and African cultural milieu in particular, imperative.

\section{Crises of faith and commitment}

This seems to be a direct consequence of the missionary oversight in the evangelisation of Africa. It has been observed that there is a crisis of commitment in the lives of sizeable number of African Christians. According to Mbefo (1989):

Despite their conversion to Christianity, many still consult the fortune tellers when they want to embark on a project. The same is true when a well thought out project flops or there is a sudden death or happenings that seem otherwise unaccounted for. 'Chance' is not in their vocabulary. Many prefer the services of the native doctors to our modern hospitals. Some find no contradiction in practicing both traditional religion and Christianity. (p. 34)

This is because Christianity as presented by the European missionaries did not fully respond to African questions and as such, has not been accepted as a way of life. Also, it has been observed that:

since the new (Christian) religion is not rooted in the African world of meaning, it lacks organic vitality and therefore in moments of crisis, many Africans revert almost instinctively to the old time 
religion which provides answers to their questions about life, about the threat of life, and about their ancestors. (Husani n.d.)

Hence, there has been disenchantment and some have fallen back to the traditional answers in the belief that the old is better'. Indeed, cases of defections of erstwhile Christian converts to African traditional religion abound in the continent. However, a case of two Catholic Priests, Dr. Vincent Damuah and Dr. Enyeribe Onuoha in Ghana and Nigeria respectively, seems more relevant here. These priests defected from the Catholic Church in order to revitalise the African religion. According to them, 'African traditional religion is not inferior to other world religions' (Mbefo 1989:32). Similarly, Kalu (1996) cited a case of Samuel Okosi, Obi of Onitsha, in Anambra state of Nigeria, who defected from Anglicanism, later became a Catholic and was excommunicated over his inextricable attachment to the indigenous culture and tradition. Communities ranged along the Lower Niger flood plain such as Odekpe, Atani, and Ogbaru through to Ossomari in the eastern part of Nigeria, were also believed to have had the same problem as they could not fully yield to Christianity because of their covenants with the gods of the river and ancestors. 'It was as if a force was dragging [them] back from full commitment' (Kalu 1996:105). These experienced crises of commitment and massive defections from the church, in the opinion of Mbefo (1989) can dispose one to affirm that Christianity has been found wanting.

\section{Christianity as a religion of the oppressors}

Africans have always found it difficult to dissociate the missionaries who brought Christianity to Africa, from the colonial masters whose imperialistic influences were deeply felt in the continent. This is because:

the missionaries that stormed the continent of Africa with the salvific message of Jesus Christ arrived from Europe on the heels of their brothers whose message was not that of liberation, but that of political, economic, and cultural subjugation in a system called colonialism. (Husani n.d.)

This historical linkage of evangelisation with colonisation has regrettably created a lasting impact on the African psyche that seems to be counterproductive for Christianity in the continent. It was as if Africans were presented with a double message - the gospel on the one hand and economic exploitation on the other. Africans could not distinguish the man who asked them to receive Jesus, from the man who asked them to pay taxes. For Africans, these men are the same; hence, the missionaries are seen as 'agents of colonialism'. Mbefo (1989) observed that:

When Africans say that the missionaries are 'agents of colonialism', they mean that missionaries used the Sermon on the Mount to reduce Africans to passivity and submissiveness and in that way made it easy for the colonialists to expropriate their lands. 'Your reward shall be in heaven' was used to break African resistance, the type exhibited by the Maumau of Kenya and the Ekumeku of the Western Igbos. (p. 40)

Furthermore, Ezechi (2011:191) has reiterated that 'Christianity had created in part the atmosphere that made the penetration of colonial government possible in the first place'. No wonder, Jomo Kenyatta said that

when the missionaries arrived, the Africans had the land and the missionaries had the Bible. They taught us to pray with our eyes closed. When we opened them, they had the land and we had the Bible. (Mbefo 1989:17)

Consequently, Africans see Christianity as the religion of the oppressors that should be substituted with a homemade Christianity.

\section{The salient issues}

There is no doubt that the task of inculturation is quite difficult, but not impossible. A critical look at the technicalities involved in the entire process, would make one wish that the first European missionaries did a proper rooting of Christianity in African culture alb initio. The task of inculturation is similar to the task of reintroduction of Christian faith in Africa in the manner that would reflect the African world views, value systems, and thought patterns in the formulation of African Christian theology; in the organisation of African Christian worship; and in the design and management of the structure of ministry and authority in the African Christian church. Hence, it is indeed an onerous task and challenge for African theologians across the continent. Pope Paul VI in 1969 reiterated this challenge when he said 'you may, and you must have an African Christianity' (Mbefo 1989:5). However, taking up this challenge to indigenise or Africanise Christianity, demands a serious caution. The following therefore, should be taken into serious consideration in order to achieve a successful inculturation of Christianity in Africa.

\section{The evolutionary African culture}

The inculturation of Christian faith in Africa is indeed imperative. The Christian faith should be made indigenous and develop from within the cultures of the people. The faith should be made a way of life of Africans in which their experiences are appealed to and aspirations met. In fact, the faith should be African.

However, while trying to make the Christian faith respond to African cultures, it should be borne in mind that African cultures have evolved or changed significantly. This is worthy of note, because the whole exercise of inculturation revolves around the recognition of African cultural specificities in the propagation and practice of the Christian faith in the continent. The fact is that over decades, the African continent has experienced significant changes in patterns of relationships ranging from the family, through the community, to the larger society. There have been significant changes in their political ideologies, economic focus, socio-cultural value systems, and religious outlook. This change is occasioned by the incidences of colonialism, slavery, missionary activities, commercial relations with the Europeans, and ceaseless breakthroughs in science and technologies.

During the nineteenth century, the European powers - Britain, France, Portugal, Spain, Italy, the Dutch, and Germany 
attacked and carved out the continent into areas of influence and shared out African people under their empires. Thereafter, foreign cultures and world view were foisted on the respective African-European territories; and at the other side, were the European missionaries who equated the African traditional religion with devilish worship, hence, 'shrines were indiscriminately destroyed and idols were pulverized; and on their sacred precincts arose schools and hospitals' (Mbefo 1989:43). As the African identity alongside its core cultural values was being replaced and substituted with a foreign identity, these core cultural values were ruefully flushed 'into vulnerable antiquity' (Mbefo 1989:40). These political and religious influences contributed largely to the historical evolution of African culture.

Therefore, it would be inaccurate to conclude that African cultures are closed systems, or unchanging. Culture as it is believed is dynamic, and African cultures are not exceptions. The precolonial Africa is greatly different from the postcolonial, modern, or contemporary Africa in which science, technologies, and digitalisation is the order of the day. In this modern or contemporary era, the unification of the countries of the world is highly enhanced into a 'global village' (i.e. globalisation). Also, more interestingly, in a global village, cultural influences are spread across the board. All these have largely contributed in the making of a 'new Africa'.

In carrying out the task of inculturation in Africa, therefore, it would be misleading to call for the recovery of African cultures in their pristine purity or the way it was being practiced by African fore-bearers before the colonial era. According to Mbefo (1989:25), 'such a call is nothing less than a call for a cultural anabaptism... and fails to take in the dimension of developmental process in all human affairs'. Achebe (2012) has lamented that there are people who do not realise that (the precolonial era) was a different world than the world of today, which is far more open. Buttressing this, Mbefo (1989) observed that:

Our exposure to other influences have made of us cultural hybrids... we, present day Africans who have gone through Western curriculum of education and speak Western languages are Africans in a way different from our ancestors who were innocent of such influences were Africans. We are Westerners in a different way in which the Westerners who have not experienced African influences are Westerners. We, present day Africans are the products of two heritages; the one foreign, the other indigenous. (p. 8)

It should however be noted that the reference to 'Western curriculum of education' does not in its strict sense or literarily refer to Western education, as one may want to argue for those set of Africans who are yet to acquire Western education. Instead, it refers to the general fact of the WesternAfrican contact and the cultural influence that ensued.

However, the fact still remains that the contemporary Africans are significantly different from the precolonial Africans. For instance, unlike the days when the abode of traditional diviners, native doctors, and herbalists looked crude with thatch roofs and so on; these days the abodes of most of them are sheer synthesis of the old and the new. Although some may be made or built with modern blocks and zinc roof tops, others may be made with mud blocks and zinc roof tops. Yet, among their sacred materials are breakable bottles and other metallic objects that might be of Western origin. All these, therefore, go to suggest that the task of inculturation in a modern Africa should be engaged wisely. The stake holders should be cautious to avoid any attempt to resuscitate 'a dead and forgotten aspect of African culture', which may be obviously irrelevant to the contemporary African society. This is because such a move would be retrogressive. There are aspects of African cultural values that have been commensurably or symmetrically replaced with Christian cultural values with the same degree of satisfaction. This is because 'there is no Christian value that is not a human value expressed differently in another cultural milieu' (Shorter 1973:66). An example is seen in the role of the African diviners and native doctors, which seem to be satisfactorily played by Christian prophets or prophetess and prayer or healing houses or ministries in Africa. Hence, the process of inculturation should be seen as a cultural dialogue of equal parties (Ezechi 2011). Both parties - African and Christianity should be seen as equal in the exchange of values for a better African Christianity. At the same time, this exercise should be done in a way that avoids losing the essence of the gospel of Christ which is to draw mankind in salvation unto himself.

\section{The unity of the church/Christendom}

The unity of the church and Christendom has been very important to Christianity. Hence, Jesus prayed 'Father, that they may be one' (John 17:11). It is the same desire that informed Ecumenical Movement in Christendom, which is aimed at the unification of all Christian denominations. This initiative dates back to the twentieth century and formed part of the issues discussed at the Second Vatican Council. According to Onwubiko (1999):

The twentieth century began with events that drew the attention of Christians of all denominations to the fact that Christian unity was a prerequisite for the mission of the church. Unity as it became clear to most Christians has been indispensable for effectiveness in Christian mission. (p. 35)

Hence, the initiative was embraced by both the Catholic and Protestant churches though in variety of approaches. The word 'ecumenism' is derived from the Greek words oikoumene (the inhabited world) and oikos (house) which literarily refers to the act of housing or accommodating the world Christian denominations separated by doctrine, history, and practice, into one umbrella in purpose and mission. Efforts have, over the years, been put to achieve this. Hence ecumenism is to the universal Christianity, what inculturation is to African Christianity.

The task of inculturation in Africa, therefore, should not be engaged in a way to truncate the ecumenical initiative. This is important because inculturation in Africa covers wide and deep areas including doctrinal, theological, and liturgical issues and so forth which are sensitive and delicate parts of Christianity. In fact, it is doctrinal differences that largely explain the denominational proliferation in Christendom. 
Therefore, in order not to further sever the relationship, cooperation and unity among Christian denominations, which is the core value of ecumenism, adequate consultation of Christian stakeholders is recommended in the inculturation exercise in Africa.

\section{Christian ecological concern}

The phenomenon of climate change alongside its devastating effects has over decades, been of great concern to world leaders, international agencies, organisations, and individuals. This ecological concern has also been taken seriously by Christians or the Christian community world over. The Christian ecological concern could be said to have been triggered by several accusations and indictments which have blamed religion and Christianity in particular, for the current state of the global climate. For instance, Nasr (1967) observed that the ecological crisis is fundamentally a crisis of values, and that religions, being the primary source of values in any culture, are thus implicated in the decisions humans make regarding the environment. In the same vein, White (1971), in his 'Historical Root of Our Ecological Crisis', specifically blamed Christianity for the current ecological crisis when he wrote that:

our science and technology have grown out of Christian attitudes towards man's relation to nature.... For nearly 2 millennia Christian missionaries have been chopping down sacred groves, which are idolatrous because they assume spirit in nature.

Although these indictments may not be absolutely justifiable, these works succeeded in awakening ecological consciousness in Christendom. Hence, for decades, the preoccupation with ecological stewardship among Christian theologians has been quite pronounced as several eco-theological perspectives have been developed.

Beyond these however, the need for ecological justice and stewardship can hardly be overemphasised. In the process of inculturation in Africa, therefore, this ecological need should be given serious attention, especially as the continent bears the brunt of the devastating impact of climate change. African theologians and other stakeholders should in understanding that 'creation is bound up with salvation' (De Gruchy 2004) reflect on the origin, purpose, and destiny of the cosmos from the point of view of faith. African cultures are replete with values and belief systems that promote the integrity of the ecosystem. Some of these values include the sacredness of the earth, reverence for life, and provision for generational continuity (CIWA 2011). African theologians should therefore relive some of these eco-friendly values in the inculturation process without distorting the main essence of the gospel of Christ.

\section{Conclusion}

This article has discussed the concept of inculturation in a modern or contemporary Africa. It has not only analysed the concept of inculturation, but also highlighted the challenge before African theologians in search of African Christianity. Three silent issues - the Evolutionary African Culture, the Unity of Christendom (ecumenism), and the Christian ecological concern, were advanced as indispensable issues which those involved in the process of inculturation in Africa would not take for granted, in order to achieve a satisfactory homemade Christian faith in the continent.

\section{Acknowledgements Competing interests}

The authors declare that they have no financial or personal relationships which may have inappropriately influenced them in writing this article.

\section{References}

Achebe, C., 2012, There was a country, Penguin Books Ltd., London.

CIWA 2011, 'A Communiqué issued at the end of the 22nd CIWA Theology Week', Held from 21st - 25th March, 2011 at the Catholic Institute of West Africa (CIWA), Port.

De Gruchy, S., 2004, 'Handout on five reasons why African Christians should be concerned about the environment', Theology and Development Studies.

Duncan, G.A., 2014, 'Inculturation: Adaptation, innovation and reflexivity. An African Christian perspective', HTS Teologiese Studies/Theological Studies 70(1), Art. \#2669, 11 pages. $\mathrm{http}: / / \mathrm{dx}$.doi.org/10.4102/hts.v70i1.2669

Ezechi, J.C., 2011, The dead never gone: Odo masquerade and contemporary realities, Monrovia Street, New Have.

Husani, G., n.d., 'Fully African, Truly Christian: The Challenge of Inculturation', viewed 30 May 2013, from http://www.georgeehusani.org

Kalu, O.U., 1996, The embattled Gods: Christianization of Igboland 1841-1991, Minaj Publishers, Lagos.

Madu, J.E., 2004, Honest to African cultural heritage, Coskan Associates Printers and Publishers, Anambra.

Mbefo, L.N., 1981, 'Nigeria's two-fold heritage', Bigard Theological Studies 2(2).

Mbefo, L.N., 1989, Towards a mature African Christianity, SNAAP Press Ltd.

Mbiti, J.S., 1969, African religions and philosophy, Heinemann Educational Books Ltd., London.

Nasr, S.H., 1967, Man and nature: The spiritual crisis in modern man, Kazi Publishers, Chicago.

Okere, T., 1974. Culture and religion, Black Academy Press, Owerri.

Onaiyekan, J., 1980, Christianity: A foreign religion, The Catholic Elite, Ibadan.

Onwubiko, O.A., 1999, Building unity together in the mission of the church: $A$ theology of ecumenism, Fulladu Publishing Company, Nsukka.

Onyeidu, S.O., 2004, Christianity and Asaba culture, Fulladu Publishers, Enugu.

Shorter, A.W.F., 1973, African culture and the Christian church: An introduction to social and pastoral anthropology, Geoffrey Chapman Publishers, London.

Viriri, A. \& Mungwini, P., 2010, 'African cosmology and the duality of Western Hegemony: The search for an African identity', The Journal of Pan African Studies $3(6), 24-42$.

Wambutda, D., 1978, An African Christian looks at Christian missions in Africa. Readings in missionary anthropology II, William Carey Library, Pasadena.

White, L., 1971, 'The historical roots of our ecological crisis', in B. John (ed.), The environmental handbook, pp. 1203-1207, Ballantine, London.

Yung, H., 2014, Mangoes or bananas: The quest for an Authentic Asian theology, Oxford Centre for Mission Studies, Oxford. 